\section{QIJEI}

\author{
International \\ Journal for \\ Educational \\ Integrity
}

\title{
Editorial Volume 7 (1)
}

I am pleased to be back at the editorial desk of the IJEI, after the wonderful guest editing work of Chris Moore and Ruth Walker on the Special Issue: Digital Technologies and Educational Integrity, Volume 6(2). With invited contributions, research articles and many reviews of recent works on the topic, 6(2) was indeed a special issue.

This current issue reflects the broad range of interests by those working in the field of academic/educational integrity. The first three papers use surveys to explore an array of inter-related topics. Robert Schrimscher, Lori Northrup and Susan Alverson, from Samford University in Alabama, surveyed their students to explore their attitudes and opinions regarding plagiarism and academic misconduct. Based on data from 681 responses, and in line with other American-based research, the authors conclude that plagiarism and other incidents of academic misconduct are on the rise, not least because students are often perplexed about faculty expectations.

Kenneth Royal, Jonathon Parrent and Ryan Clark from the University of Kentucky also based their research on a survey, but one that was quite different to the surveys traditionally conducted. The purpose of their study was to construct a psychometric ruler that illustrated undergraduate education majors' perceptions of academic misconduct. Utilising Item Response Theory (IRT), specifically Rasch measurement, to analyse data from 114 students' responses to 38 descriptions of academic misconduct, the authors were able to demonstrate which behaviours students considered the most and the least severe, with some interesting results.

Across the Pacific, Guy Curtis and Razma Popal conducted a five year follow-up survey on both rates and perceptions of plagiarism by students at the University of Western Sydney in New South Wales. Comparing data between the 2004 and 2009 surveys, the authors conclude that there had been a reduction in the prevalence of plagiarism and an increase in both understanding and perceived seriousness of the issue during the five year period. In company with most researchers and practitioners working in the area, Curtis and Popal suggest that plagiarism may be reduced by means of educative rather than punitive means.

Writing from a very different context, Patient Rambe (University of the Free State) and Munyaradzi Mawere (University of Cape Town), interrogate the critical literacy policy and practices of the Mozambican educational system. Echoing the work of Nigerian authors Nwaopara, Ifebhor and Ohiwerei, who explored the egregious breaches of integrity in the Nigerian education system in Volume 4(1) of this journal in 2008, Rambe and Mawere convincingly argue that the educational landscape and new curriculum have both undermined possibilities for Mozambican learners to become self-critical, and compromised the quality of education against regional and international standards. This powerful article reminds those of us in the privileged West that academic integrity goes well beyond writing conventions and citation practices. Integrity is central to every aspect of education, and has an impact on crucial issues such as student attendance, attrition, gender ratios, training and professional development of teachers, safety of students on campus, the role of administrators and parents, the efficacy of everyday learning, and the reliability of examination results, to mention just a few.

The International Journal for Educational Integrity is available online at:

http://www.ojs.unisa.edu.au/journals/index.php/lJEl/

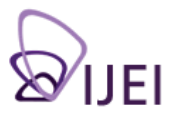


The final refereed article in this issue points to the impact of new technologies and digital media on conceptions and practices of academic misconduct. Christopher M. Seitz, Muhsin Michael Orsini and Meredith R. Gringle, from the University of Carolina in Greensboro, investigated the video sharing website www.youtube.com for the presence of instructional videos that teach students how to cheat on academic work. Forty-three videos were analysed to determine the methods of cheating, the popularity of the videos, the demographics of viewers and those uploading the videos, and the opinions of viewers after watching these types of videos. Not surprisingly, the study's results suggest that instructional cheating videos are popular among students around the world.

The five refereed papers in this issue demonstrate the diversity of research in the area of academic/educational integrity. Much of the work occurring in the United States tends to use a survey approach to determine college students' attitudes and practices, while work elsewhere tends to take a broader approach to the issue. The IJEI has received numerous submissions from researchers in African nations since the Nwaopara, Ifebhor and Ohiwerei article in 2008, although to date the submissions have not been of an appropriate standard for an international audience. The message, however, has been clear and consistent - educational systems in many African nations are undermined by corruption and breaches of integrity at almost every level. It is therefore especially pleasing that this issue includes Rambe's and Mawere's important contribution.

The issue concludes with a review of Tricia Bertram Gallant's new edited volume, Creating the ethical academy: A systems approach to understanding misconduct and empowering change in higher education (Routledge 2011). This book focuses on the development of a theoretical framework from which to view academic integrity.

Bertram Gallant goes well beyond the limited lens of blaming students for their poor behaviour or their moral failure. In this book she successfully achieves her two stated purposes: to illustrate that ethical misconduct should be viewed as a systemic (rather than individual) issue and to encourage higher education stakeholders to make ethics a strategic institutional priority. We are honoured to have Tricia Bertram Gallant as a member of the Editorial Board of the IJEI and commend her latest volume to our readers.

I hope you enjoy Volume 7(1). If you have any queries, concerns or suggestions for a special issue, please contact me directly at tracey.bretag@unisa.edu.au.

Tracey Bretag, IJEI Editor, June 2011. 